\title{
Biocontrol of Korean Ginseng Root Rot Caused by Phytophthora cactorum Using Antagonistic Bacterial Strains ISE13 and KJ1R5
}

\author{
Mee Kyung Sang', Mae Hee Chiang ${ }^{2}$, Eun Seob Yi ${ }^{3}$, Kuen Woo Park ${ }^{1}$ and Ki Deok Kim ${ }^{1 *}$ \\ 'Division of Bioscience and Technology, College of Life and Environmental Sciences, Korea University, Seoul 136-713, Korea \\ ${ }^{2}$ Division of Environmental and Life Sciences, College of Natural Sciences, Seoul Women's University, Seoul 139-774, Korea \\ ${ }^{3}$ Gyeonggido Agricultural Research and Extension Service, Hwasung 445-927, Korea
}

(Received on November 7, 2005; Accepted on November 23, 2005)

In this biocontrol research, we evaluated disease suppressive effects of antagonistic bacterial strains ISE13 and KJ1R5 against Korean ginseng root rot caused by $P$. cactorum. We also examined the effects of nutrient solution in the hydroponic culture system for Korean ginseng on biological activity of the bacterial strains. As results of dual culture tests of the bacterial strains on $V_{8}$ juice agar, the strain ISE13 showed antifungal activity against $P$. cactorum and other plant pathogenic fungi, but the strain KJ1R5 did not. When their inhibitory effects against infection of $P$. cactorum on the roots grown in either nutrient solution or water were tested, the strains ISE13 and KJ1R5 inhibited the disease severity of Korean ginseng roots only grown with water, compared to buffer-treated, inoculated controls. However, the nutrient solution used for hydroponic cultures of ginseng in pots caused higher levels of disease severity by the strains ISE13 and KJ1R5 from 18.8\% to $40.0 \%$ and from $24.3 \%$ to $45.0 \%$, respectively. In this study, the bacterial strains ISE13 and KJ1R5 could be potentially biocontrol agents to suppress Korean ginseng root rot caused by $\boldsymbol{P}$. cactorum. However, more attention using nutrient solution in hydroponic cultures for Korean ginseng production should be applied in biocontrol of plant diseases using the antagonistic microorganisms.

Keywords : antagonistic bacteria, biocontrol, Korean ginseng, Phytophthora cactorum, root rot

Biocontrol of plant diseases using microorganisms has been attempted as an alternative measure to agricultural chemicals due to high cost of their application, and potential hazards to the environments, toxicity to crops, and the development of fungicide-resistant strains of plant pathogens (Haas and Defago, 2005; Handelsman and Stabb, 1996). A number of antagonistic bacteria from rhizosphere soils and interior of plants have been potential as biocontrol agents and plant

\footnotetext{
*Corresponding author.

Phone) +82-2-3290-3065, FAX) +82-2-925-1970

E-mail) kidkim@korea.ac.kr
}

growth-promoting rhizobacteria. Especially these antagonistic bacteria were effective to reduce development of soilborne pathogens such as Phytophthora spp., Fusarium spp., and Rhizoctonia spp. (Knudsen et al., 1997).

Korean ginseng (Panax ginseng C.A. Meyer) has usually been cultivated for a long period from 3 to 5 years in a field that could generate side-effects of the production. To avoid the effects from continuous cultivation of Korean ginseng, nutrient cultures for its production has also been searched (Park et al., 2002). The continuous cultivation caused many problems including plant diseases caused by $P$. cactorum, Cylindrocarpon destructans, $F$. solani, and $R$. solani (Reeleder and Brammall, 1994; Punja, 1997). Among these pathogens, $P$. cactorum caused root rot of ginseng for loss of its yield and reduction of its quality (Bobev et al., 2003). In addition, since Korean ginseng was used as a medicinal plant that caused to difficult to apply for chemicals, alternatively biocontrol with antagonists would be desirable to reduce root rot of ginseng by P. cactorum (Jeffers et al., 2004). In this study, we evaluated disease suppressive effects of potentially antagonistic bacterial strains ISE13 and KJ1R5 to Korean ginseng root rot by $P$. cactorum. We also examined the effects of nutrient solution in hydroponic cultures for Korean ginseng in the greenhouse on biological activity of the bacterial strains against root infection of $P$. cactorum.

Antifungal activity of bacterial strains ISE13 and KJ1R5 selected from our preliminary experiments (Kim et al., 2003) was tested against ginseng root rot fungus $P$. cactorum and other plant pathogenic fungi including Alternaria mali, F. oxysporum f. sp. lycopersici, and Magnaporthe grisea. The bacterial strains ISE13, KJ1R5 or sterile water as a control were streaked in a line down the centers of $V_{8}$ juice agar and incubated for 24 hours. Then, the mycelial plugs ( $5 \mathrm{~mm}$ in diameter) from the actively growing 5-day-old cultures of the fungi were put on both sides of the $V_{8}$ juice agar. Inhibition of mycelial growth of the fungi by the strains ISE13 and KJ1R5 was measured when fungal mycelia in the water controls reached the center of the media. The experiments were conducted with six repli- 
cations in which one replication indicated the mean of the two measurements of each test plate.

Suppressive effects of the bacterial strains ISE13 and KJ1R5 against $P$. cactorum were tested on ginseng in vitro experiments. Roots (1 year old) of Korean ginseng (var. Jagyungjong) were transplanted and grown in pots containing with potting mixtures [Peat moss (Acadian Peat Moss Ltd., Lamègue, New Brunswick, Canada), perlite, and vermiculite, $5: 3: 2, \mathrm{v} / \mathrm{v} / \mathrm{v}]$ in the greenhouse. One hundred $\mathrm{ml}$ of nutrient solution $\left[\mathrm{Ca}\left(\mathrm{NO}_{3}\right)_{2} \cdot 4 \mathrm{H}_{2} \mathrm{O} 1.0 \mathrm{~g}, \mathrm{KNO}_{3} 0.9 \mathrm{~g}, \mathrm{KH}_{2} \mathrm{PO}_{4}\right.$ $0.3 \mathrm{~g}, \mathrm{MgSO}_{4} \cdot 7 \mathrm{H}_{2} \mathrm{O} 0.3 \mathrm{~g}$, FeEDTA $42.0 \mathrm{mg}, \mathrm{MnSO}_{4} \cdot 5 \mathrm{H}_{2} \mathrm{O}$ $1.8 \mathrm{mg}, \mathrm{CuSO}_{4} \cdot 7 \mathrm{H}_{2} \mathrm{O} 0.1 \mathrm{mg}, \mathrm{ZnSO}_{4} \cdot 7 \mathrm{H}_{2} \mathrm{O} 1.0 \mathrm{mg}, \mathrm{H}_{3} \mathrm{BO}_{3}$ $\left.1.6 \mathrm{mg}, \mathrm{Na}_{2} \mathrm{MoO}_{4} \cdot 2 \mathrm{H}_{2} \mathrm{O} 0.1 \mathrm{mg}, 1 \mathrm{~L} \mathrm{H}_{2} \mathrm{O}\right]$ or water were drenched into pots at every 4 days for about 60 days since initial leaves from the roots were developed about 30 days after transplanting. For in vitro inoculation tests, Korean ginseng roots from the pots were obtained and adhesive soils of roots were removed by shaking manually in sterile water. Thereafter the roots were surface-sterilized with $1 \%$ hypochlorite for $90 \mathrm{sec}$, rinsed several times with sterile water and blotted on sterile filter papers.

The bacterial strains ISE13 and KJ1R5 stored in nutrient broth (NB, Difco, Detroit, MI, U.S.A.) with $20 \%$ glycerol at $-70^{\circ} \mathrm{C}$ were streaked onto nutrient agar (NA) and incubated at $28^{\circ} \mathrm{C}$ for $48 \mathrm{~h}$. Single colony from NA was inoculated in $5 \mathrm{ml}$ of $\mathrm{NB}$ and incubated in a shaking incubator $(160 \mathrm{rpm})$ at $28^{\circ} \mathrm{C}$ for $24 \mathrm{~h}$. These pre-cultured bacterial strains were transferred to $500 \mathrm{ml}$ of $\mathrm{NB}$ and incubated again in a shaking incubator $(160 \mathrm{rpm})$ at $28^{\circ} \mathrm{C}$ for $48 \mathrm{~h}$. The bacterial cells were harvested with $10 \mathrm{mM}$ $\mathrm{MgSO}_{4}$ buffer through centrifugation at $5,000 \mathrm{~g}$ at $20^{\circ} \mathrm{C}$ for $15 \mathrm{~min}$ to eliminate culture media. After centrifugation, the supernatants were discarded and pellets (bacterial cells) were washed twice with the buffer by centrifugation. Bacterial suspensions were adjusted to $10^{8}$ cells per $\mathrm{ml}$. The roots prepared as above were dipped into these bacterial suspensions for 30 minutes and then dried on sterile filter papers. The $10 \mathrm{mM} \mathrm{MgSO}_{4}$ buffer served as untreated controls.

For preparation of zoospore inoculum, $P$. cactorum was grown on $V_{8}$ juice agar for 7 days at $28^{\circ} \mathrm{C}$ and incubated under fluorescent light for 4 days at $28^{\circ} \mathrm{C}$ for inducing sporangia. The cultures were then added with chilled sterile water and stored for $30 \mathrm{~min}$ at $4^{\circ} \mathrm{C}$, following by $30 \mathrm{~min}$ at the room temperature to release zoospores from sporangia. Fifty $\mu 1$ of $P$. cactorum zoospores $\left(4 \times 10^{5}\right.$ zoospores $\left./ \mathrm{ml}\right)$ were drop-inoculated on the prepared Korean ginseng roots in petri dishes containing moist filter papers. The inoculated roots in the petri dishes were again put in a container at $28^{\circ} \mathrm{C}$. Water served as uninoculated controls. Percent disease severity of each inoculated ginseng root was visually evaluated 4 days after drop-inoculation. The experiments

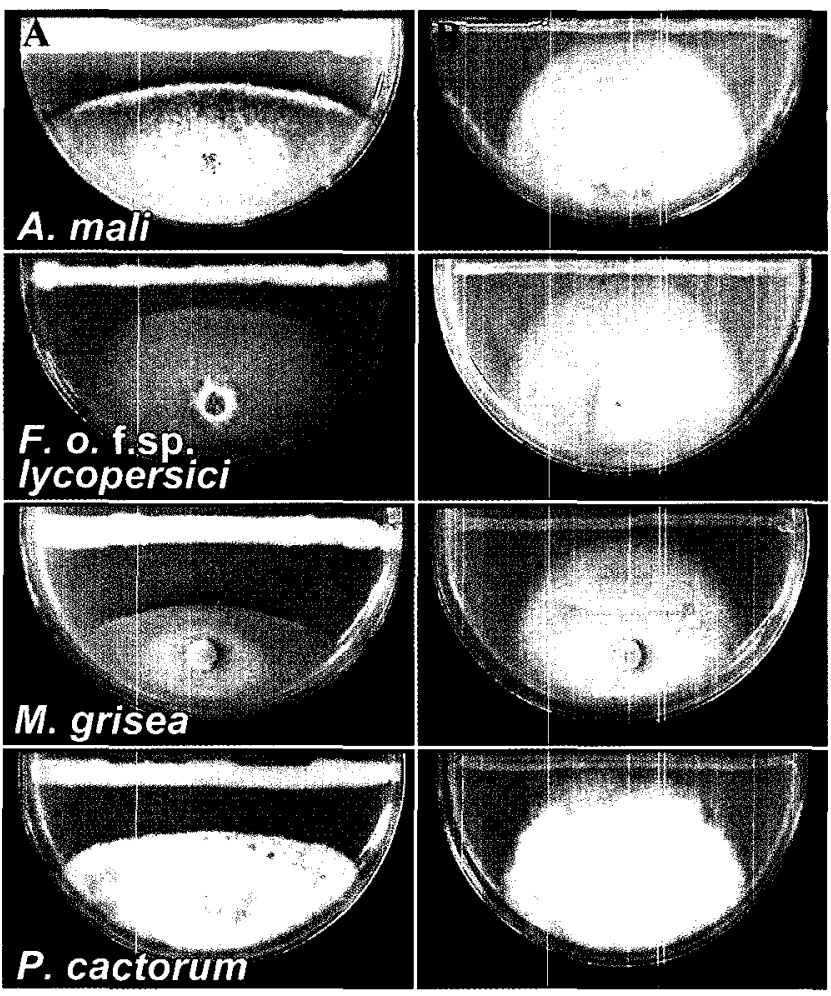

Fig. 1. Inhibition of mycelial growth of four plant pathogenic fungi, Alternaria mali, Fusarium oxysporum f.sp. lycopersici, Magnaporthe grisea, Phytophthora cactorum by antagonistic bacterial strains (A) ISE13 and (B) KJ1R5. Pictures were taken when fungal mycelia in water controls reached the centers of the $\mathrm{V}_{8}$ juice agar plates.

Table 1. Antifungal activity of antagonistic bacterial strains ISE13 and KJ1R5 against plant pathogenic fungi on $\mathrm{V}_{8}$ juice agar

\begin{tabular}{cccrc}
\hline \hline \multirow{2}{*}{$\begin{array}{c}\text { Bacterial } \\
\text { strain }\end{array}$} & \multicolumn{4}{c}{ Inhibition zone $(\mathrm{mm})^{\mathrm{a}}$ of mycelial growth } \\
\cline { 2 - 5 } & $\mathrm{AM}^{\mathrm{b}}$ & $\mathrm{FOL}$ & \multicolumn{1}{c}{$\mathrm{MG}$} & \multicolumn{1}{c}{$\mathrm{PC}$} \\
\hline ISE13 & $9.0 \pm 1.7^{\mathrm{c}}$ & $4.3 \pm 0.6$ & $12.7 \pm 0.6$ & $8.1 \pm 0.2$ \\
KJ1R5 & $1.7 \pm 0.6$ & $1.7 \pm 1.0$ & $1.3 \pm 0.6$ & $2.3 \pm 0.3$ \\
\hline
\end{tabular}

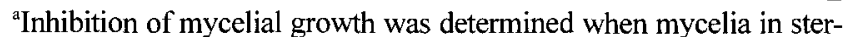
ile water controls reached the centers of the $\mathrm{V}_{8}$ juice agar plates.

'AM, Alternaria mali; FOL, Fusarium oxysporum f.sp. lycopersici; MG, Magnaporthe grisea; PC, Phytophthora cactorum.

'Values are means and standard deviations of six replications.

were conducted with eight replications.

As results of dual culture tests of bacterial strains, strain ISE13 had antifungal activity against $P$. cactorum and other plant pathogenic fungi on $V_{8}$ juice agar, but strain KJ1R5 had slight activity to the test fungi (Fig. 1 and Table 1). The bacterial strain ISE13 inhibited effectively mycelial growth of $A$. mali, $M$. grisea, and $P$. cactorum in the range of about 8-13 mm. However, strain KJ1R5 inhibited mycelial growth of the test fungi with only about 1-2 mm (Table 1). These results would suggest that strain ISE13, but not strain 


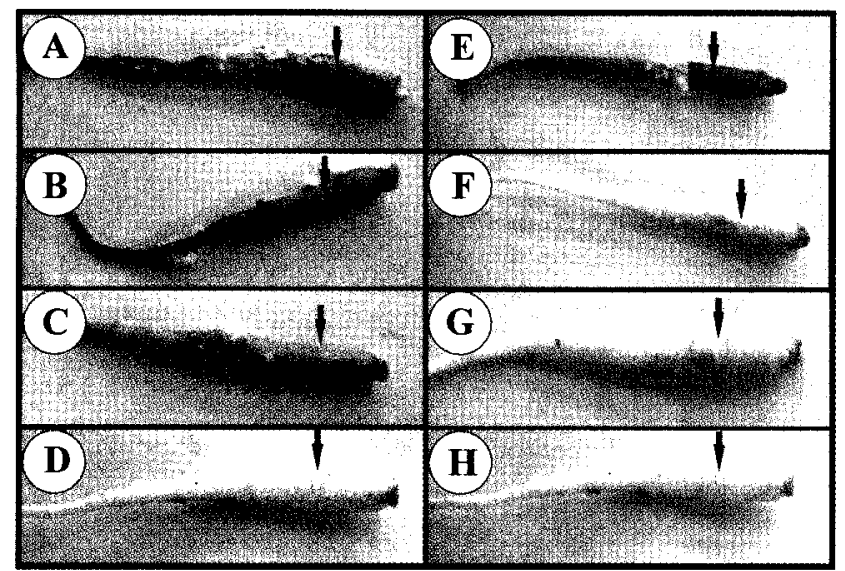

Fig. 2. Disease symptoms of Korean ginseng roots 4 days after drop-inoculation with zoospores of Phytophthroa cactorum. Sites of drop-inoculations on Korean ginseng roots were indicated by arrows. $\mathrm{A}$ and $\mathrm{E}$; inoculated controls treated with $\mathrm{MgSO}_{4}$ buffer solution, $\mathrm{B}$ and $\mathrm{F}$; treated with the antagonistic bacterial strain ISE13, $\mathrm{C}$ and $\mathrm{G}$; treated with the antagonistic bacterial strain KJ1R5, D and H; uninoculated controls treated with the buffer solution. Korean ginseng roots (A, B, C, and D) for inoculation experiments were initially grown in pots applied with nutrient solution or water (E, F, G and $\mathrm{H})$, respectively.

Table 2. Effects of antagonistic bacterial strains ISE13 and KJ1R5 on disease severity of Korean ginseng roots inoculated with Phytophthora cactorum

\begin{tabular}{lcc}
\hline \hline \multirow{2}{*}{ Treatment } & \multicolumn{2}{c}{ Disease severity $(\%)^{\mathrm{a}}$} \\
\cline { 2 - 3 } & Nutrient solution $^{\mathrm{b}}$ & Water \\
\hline ISE13 & $40.0^{\mathrm{c}} \pm 9.8$ & $18.8 \pm 4.4$ \\
KJ1R5 & $45.0 \pm 12.5$ & $24.3 \pm 10.0$ \\
Inoculated control $^{d}$ & $46.3 \pm 10.5$ & $43.3 \pm 10.2$ \\
Uninoculated control $^{\mathrm{a}}$ & $0.0 \pm 0.0$ & $0.0 \pm 0.0$
\end{tabular}

${ }^{a}$ Disease severity (\%) of each inoculated ginseng root was assessed 4 days after drop-inoculation with zoospores of Phytophtora cactorum.

${ }^{\mathrm{b}}$ Korean ginseng roots for inoculation were initially grown in pots applied with nutrient solution or water, respectively.

'Values are means and standard deviations of eight replications.

${ }^{\mathrm{d}}$ Korean ginseng roots inoculated with $P$. cactorum or water served as inoculated and uninoculated controls, respectively.

KJ1R5, produced antifungal compounds associated with disease suppression as observed in other researches (Chang et al., 2000; Rodriquez and Pfender, 1997).

When inhibitory effects of bacterial strains ISE13 and KJ1R5 against infection of $P$. cactorum were tested using Korean ginseng roots grown with either nutrient solution or water, inhibitory effects of the strains were observed only on Korean ginseng roots grown with water (Fig. 2 and Table 2). Both strains ISE13 and KJ1R5 significantly reduced disease severity of Korean ginseng root rot caused by $P$. cactorum compared to buffer-treated, inoculated controls. However, nutrient solution used for hydroponic cultures of ginseng in pots caused higher levels of disease severity by the antagonistic strains ISE13 and KJ1R5 from $18.8 \%$ to $40.0 \%$ and from $24.3 \%$ to $45.0 \%$, respectively (Table 2). As observed in our study, Shaukat and Siddiqui (2003) also observed this phenomenon that mineral and carbon sources influenced the biocontrol performance of $P$ sudomonas aeruginosa and $P$. fluorescens to Macrophomina phaseolina. Thus they suggested that components of nutrient solutions in hydropnic cultures could either increase or decrease the biocontrol efficacy of microbial antagonists.

In this study, the bacterial strains ISE13 and KJ1R5 could be potential biocontrol agents to suppress Korean ginseng root rot caused by $P$. cactorum. The suppression of Korean ginseng root rot by the strains ISE13 and KJ1R5 might be achieved through at least one of mechanisms among antibiosis, colonization, competition, and/or inducing host resistance (Haas and Defago, 2005; Handelsman and Stabb, 1996). In addition, more attention using nutrient solution in hydroponic cultures for Korean ginseng production should be applied in biocontrol of plant diseases.

\section{Acknowledgments}

This study was supported by a grant from Korea Sanhak Foundation in 2004. We thank to Dr. Yeoung-Seuk Bae, Rural Development Administration, Suwon, Korea, for providing Phytophthora cactorum used in this study.

\section{References}

Bobev, S. G, Baeyen, S., Crepel, C. and Maes, M. 2003. First report of Phytophthora cactorum on American ginseng (Panax quinquefolius) in Bulgaria. Plant Dis. 87:752.

Chang, S. H., Lee, J. Y., Kim, K. D. and Hwang, B. K. 2000. Screening for in vitro antifungal activity of soil bacteria against plant pathogens. Mycobiology 28:190-192.

Haas, D. and Defago, G. 2005. Biological control of soil-borne pathogens by fluorescent pseudomonads. Nature Rev. Microbiol. 3:307-319.

Handelsman, J. and Stabb, E. V. 1996. Biocontrol of soilborne plant pathogens. Plant Cell 8:1855-1869.

Jeffers, S. N., Schnabel, G and Smith, J. P. 2004. First report of resistance to mefenoxam in Phytophthora cactorum in the United States and elsewhere. Plant Dis. 88:576.

Kim, H. S., Myung, I.-S. and Kim, K. D. 2003. Identification of an antagonistic bacterium, KJIR5, for biological control of Phytophthora blight of pepper. Plant Pathol. J. 19:320.

Knudsen, I. M. B., Hockenhull, J., Funck, J. D., Gerhardson, B., Hökeberg, M., Tahvonen, E. R. Teperi, Sundheim, L. and Henriksen, B. 1997. Selection of biological control agents for controlling soil and seed-borne diseases in the field. Eur. $J$. 
Plant Pathol. 103:775-784.

Park, K. W., Yang, D. S. and Lee, G. P. 2002. Effect of substrate on the production of Korean ginseng (Panax ginseng C.A. Meyer) in nutrient culture. J. Bio-Environment Control 11:199-204.

Punja, Z. K. 1997. Fungal pathogens of America ginseng (Panax quinquefolius) in British Columbia. Can. J. Plant Pathol. 19:301-306.

Reeleder, R. D. and Brammall, R. A. 1994. Pathogenicity of Pythium species, Cylinderocarpon destructans and Rhizoctonia solani to ginseng seedling in Ontario. Can. J. Plant Pathol. 16:311-316.

Rodriquez, F. and Pfender, W. F. 1997. Antibiosis and antagonism of Sclerotinia homoeocarpa and Drechslera poae by Pseudomonas fluorescens Pf-5 in vitro and in planta. Phytopathology 87:614-621.

Shaukat, S. S. and Siddiqui, I. A. 2003. The influence of mineral and carbon sources on biological control of charcoal rot fungus, Macrophomina phaseolina by fluorescent pseudomonads in tomato. Lett. Appl. Microbiol. 36:392-398. 